\title{
EVALUASI EFEKTIVITAS PENERAPAN SISTEM AKUNTANSI PENGELUARAN KAS ATAS UANG PERSEDIAAN (UP) PADA DINAS PERTANIAN DAN PETERNAKAN PROVINSI SULAWESI UTARA
}

\author{
EVALUATION OF THE EFFECTIVENESS OF THE APPLICATION OF THE ACCOUNTING SYSTEM OF \\ CASH EXPENDITURE ON THE MONEY SUPPLY IN THE DEPARTMENT OF AGRICULTURE AND \\ ANIMAL HUSBANDRY IN NORTH SULAWESI PROVINCE
}

\author{
Oleh : \\ Betriana Frisly Polii ${ }^{1}$ \\ Lidia Mawikere ${ }^{2}$ \\ ${ }^{1,2}$ Fakultas Ekonomi dan Bisnis, Jurusan Akuntansi \\ Universitas Sam Ratulangi \\ email: ${ }^{1}$ frislypolii@gmail.com \\ ²lidiamawikere76@gmail.com
}

\begin{abstract}
Abstrak: Peranan pemerintah daerah yang mengelolah keuangan daerahnya sendiri sebagai upaya untuk mengoptimalkan potensi pendapatan pada tiap-tiap daerah guna meningkatkan perkembangan daerah tersebut. Penelitian ini bertujuan untuk mengetahui penerapan sistem akuntansi pengeluaran kas atas Uang Persediaan (UP) di Dinas Pertanian dan Peternakan Provinsi Sulawesi Utara.Metode yang digunakan yaitu deskriptif kualitatif.Hasil penelitian menunjukkan pelaksanaan sistem akuntansi pengeluaran kas atas uang persediaan di Dinas Pertanian dan Peternakan Provinsi Sulawesi Utara telah dilakukan sesuai dengan teori sistem akuntansi pengeluaran kas serta aturan yang ada.Diharapkan adanya pelatihan dalam bidang akuntansi agar dalam proses kinerja dapat berjalan sesuai yang diharapkan.
\end{abstract}

Kata Kunci : Sistem Akuntansi Pengeluaran Kas, Uang persediaan, Efektivitas Penerapan.

\begin{abstract}
The role of local governments that manage their own regional finance in an effort to optimize the revenue potential of each region in order to enhance the development of the area. This study aims to determine the application of the accounting system of cash expenditure on Money Supply (UP) in the Department of Agriculture and Animal Husbandry of North Sulawesi Province. The method used is descriptive qualitative. The results showed the implementation of the accounting system of cash expenditure on the money supply in the Department of Agriculture and Animal Husbandry of North Sulawesi province has been conducted in accordance with the theory of cashexpenditure accounting system as well as the existing rules. Expected training in accounting in order to process performance can be run as expected.
\end{abstract}

Keywords: Accounting, Accounts Payable, Moneysupply, Effectiveness Ofimplementation. 


\section{PENDAHULUAN}

\section{Latar Belakang}

Peranan pemerintah daerah yang mengelolah keuangan daerahnya sendiri sebagai upaya untuk mengoptimalkan potensi pendapatan pada tiap-tiap daerah guna meningkatkan perkembangan daerah tersebut, pendapatan pada tiap-tiap daerah tersebut harus maksimal. Seperti ditegaskan dalam UU No. 32 Tahunn 2004 bahwa otonomi daerah menggunakan prinsip otonomi seluas-luasnya dalam arti daerah diberikan kewenangan mengurus dan mengatur semua urusan pemerintahan di luar urusan pemerintah pusat yang ditetapkan dalam undang-undang tersebut. Oleh sebab itu, penyelenggaraan otonomi daerah harus selalu berorientasi pada peningkatan kesejahteraan masyarakat dengan selalu memperhatikan kepentingan dan aspirasi yang tumbuh dalam masyarakat. Untuk itu, otonomi daerah diharapkan dapat menciptakan efisiensi dan efektivitas pengelolaan sumber daya daerah, meningkatkan kualitas pelayanan umum dan kesejahteraan masyarakat, dalam membudayakan dan menciptakan ruang bagi masyarakat untuk ikut berpartisipasi dalam proses pembangunan. (Tanjung $2012: 23$ )

Penyusunan laporan keuangan yang memenuhi asas tertib, transparansi, akuntabilitas, konsistensi, komparabilitas, akurat, dapat dipercaya dan mudah dimengerti, perlu disusun sistem dan prosedur akuntansi dalam pengelolaan Anggaran Pendapatan dan Belanja Daerah (APBD).Anggaran Pendapatan dan Belanja Daerah (APBD) merupakan kebijaksanaan keuangan tahunan Pemerintah Daerahyang disusun berdasarkan ketentuan perundang-undangan yang berlaku, serta berbagai pertimbangan lainnya dengan maksud agar penyusunan, pemantauan, pengendalian dan evaluasi APBD mudah dilakukan.

APBD adalah Anggaran Pendapatan dan Belanja suatu daerah untuk satu tahun berjalan (1 periode) yang ditetapkan dengan Peraturan Daerah (Perda).APBD disusun oleh Badan Eksekutif (Pemerintah Provinsi) dan Legislatif (DPRD).Salah satu tujuan dibuat anggaran adalah untuk membiayai seluruh belanja rutin pegawai dan kegiatan publik dalam rangka meningkatkan kesejahteraan rakyat. Selanjutnya tahap pelaksanaan APBD adalah proses pelaksanaan pembiayaan pembangunan yang dilakukan oleh Pemerintah Provinsi ini kemudian selama tahun anggaran berjalan. Setelah tahap pelaksanaan ini kemudian dilanjutkan dengan proses pertanggungjawaban yang dilakukan oleh Gubernur kepada DPRD Provinsi untuk diberikan penilaian.

Instansi pemerintahan yang memiliki kewajiban untuk menyelenggarakan penyusunan, pelaksanaan dan pelaporan APBD, Pemerintah Daerah Provinsi Sulawesi Utara telah melaksanakan proses penganggaran sesuai dengan Peraturan Daerah (Perda) yang berlaku. Kemudian menyusun dan melaksanakan kegiatan APBD dengan mengacu pada Permendagri Nomor 57 Tahun 2007 sebagai pedoman pelaksanaan, penatausahaan hingga laporan keuangan dimana mencakup kebijakan akuntansi yang merupakan dasar yang harus dipatuhi dalam menyusun laporan keuangan.

Dinas Pertanian dan Peternakan sebagai salah satu Satuan Kerja Perangkat Daerah di lingkup Pemerintah Provinsi Sulawesi Utara dalam kegiatannya menggunakan dana APBN dan APBD. Dana APBD yang tertuang dalam DPA diupayakan semaksimal mungkin untuk pencapaian realisasinya disesuaikan dengan anggaran kas dan target yang ditentukan.Fenomena yang terjadi pada Dinas Pertanian dan Peternakan Provinsi Sulawesi Utara adalah terjadinya keterlambatan dalam penyerapan anggaran khususnya dalam penggantian penggunaan uang persediaan (UP) dalam bentuk Ganti Uang (GU). Dimana dalam memulai aktivitasnya, Dinas Pertanian dan Peternakan Provinsi Sulawesi Utara mendapat Uang Persediaan (UP) yang bentuk pertanggungjawabannya dalam bentuk Ganti Uang (GU).

\section{Tujuan Penelitian}

Penelitian ini bertujuan untuk mengetahui penerapan sistem akuntansi pengeluaran kas atas uang persediaan (UP) di Dinas Pertanian dan Peternakan Provinsi Sulawesi Utara.

\section{TINJAUAN PUSTAKA}

Pengertian Akuntansi menurut Accounting Principle Board (APB) Statement no. 4 dalam Sofyan Syafri Harahap (2009:4) sebagai berikut : Akuntansi adalah suatu kegiatan jasa. Fungsinya adalah memberikan informasi kuantitatif umumnya dalam ukuran uang, mengenai suatu badan ekonomi yang dimaksudkan, untuk digunakan dalam pengambilan keputusan ekonomi sebagai dasar memilih diantara beberapa alternatif. 


\section{Akuntansi Sektor Publik}

Sistem akuntansi untuk badan-badan pemerintahan harus mengikuti standar akuntansi pemerintah (SAP) seperti dimaksud dalam undang-undang nomor 17 tahun 2003 pasal 32, undang-undang nomor 1 tahun 2004 pasal 51 ayat 3, dan peraturan pemerintah nomor 24 tahun 2005. Di sisi lain, unit-unit pemerintah yang bergerak di bidang bisnis (BUMN dan BUMD) harus mengikuti standar akuntansi keuangan yang dikeluarkan oleh IAI (ikatan akuntansi Indonesia).

\section{Sistem Informasi Akuntansi Pengeluaran Kas}

Sistem informasi akuntansi pengeluaran kas terbagi menjadi dua bagian yaitu sistem informasi akuntansi pengeluaran kas dengan cek dan sistem dana kas kecil. Sistem informasi akuntansi pengeluaran kas dengan cek adalah pengeluaran kas dengan menggunakan cek dan pengeluaran kas dengan menggunakan cek biasanya karena jumlahnya relatif besar. (Mulyadi 2008)

Catatan Yang Digunakan

a. Jurnal pengeluaran kas (Cash Disbursement Journal)

b. Register Cek (Check Register)

Dokumen-Dokumen Yang Digunakan

1. Bukti kas keluar

2. Cek

3. Permintaan cek (Check Request)

\section{Prosedur Pengeluaran Kas}

Menurut Soemarso S.R (2009) untuk dapat menghasilkan sistem pengawasan yang baik, prosedur pengeluaran uang harus memprhatikan hal sebagai berikut:

1. Semua pengeluaran dilakukan dengan cek, pengeluaran-pengeluaran dalam jumlahkecil dilakukan melalui dana kas kecil.

2. Semua pengeluaran kas harus memperoleh persetujuan dari yang berwenang terlebih dahulu.

3. Terdapat pemisahan tugas antara yang berhak menyetujui pengeluaran kas, yang menyimpan uang kas dan melakukan pengeluaran kas serta yang mencatat pengeluaran kas.

\section{Penelitian Terdahulu}

Umbuan V, 2012, Perancangan Sistem Informasi akuntansi, kasus pada PT Permata Bangun Perkasa Mandiri Manado. Tujuan dari penelitian ini adalah untuk merancang sistem informasi akuntansi yang disajikan dalam bentuk bagan alir dan dokumen-dokumen pendukung kegiatan operasional. Metode serta teknik yang digunakan dalam penelitian ini adalah mengumpulkan data-data dari perusahaan yang berupa data kualitatif yang disajikan secara deskriptif dan mengelolanya sesuai dengan landasan teori Diharapkan perancangan Sistem Informasi akuntansi tersebut dapat membantu perusahaan dalam menerapkan sistem akuntansi yang tepat dan sesuai.

\section{Jenis Penelitian}

\section{METODE PENELITIAN}

Penelitianini menggunakan metode yang deskriptif kualitatif yaitu berupa studi kasus dan studi pustaka.Studi kasus dilakukan pada Dinas Pertanian dan Peternakan Provinsi Sulawesi Utara, sedangkan studi pustaka dilakukan dengan mengumpulkan data dari literature-literatur yang relevan dengan permasalahan Akuntansi Pengeluaran Kas. Metode penelitian yang digunakan pada penelitian ini yaitu dengan cara mencari,mengumpulkan dan menganalisis data dengan melakukan perbandingan antara teori-teori dengan data objektif yang terjadi pada subjek penelitian sehingga memberikan gambaran lengkap permasalahan penelitian dan cara penyelesaiannya. Dengan cara data dan keterangan yang telah dikumpulkan, diolah dan dianalisis sehingga sampai pada suatu kesimpulan yang relevan.

\section{Tempat dan Waktu Penelitian}

Penelitian dilaksanakan di Dinas Pertanian dan Peternakan Provinsi Sulawesi Utara. Periode waktu dimulai dari bulan Januari 2015 sampai dengan skripsi diseminarkan 


\section{Prosedur Penelitian}

Dalam upaya mengevaluasipenerapan sistem akuntansi pengeluaran kas atas uang persediaan (UP) pada Dinas Pertanian dan Peternakan Provinsi Sulawesi Utara.Maka prosedur penelitian yang akan dilakukan yaitu sebagai berikut :

1. Mengidentifikasi dan merumuskan masalah yang dihadapi dinasPertanian dan Peternakan Provinsi Sulawesi Utara.

2. Mengetahui proses serta akuntansi pengeluaran kas.

3. Menganalisis kinerja belanja dalam laporan realisasi anggaran

4. Menarik kesimpulan dan memberikan saran berdasarkan analisis kinerja belanjan dalam laporan realisasi anggaran pada Dinas Pendapatan Kota Manado.

\section{Metode Pengumpulan Data}

Metode pengumpulan data menggunakan metode analisis deskriptif kualitatif yaitu metode dimana data yang dikumpulkan disusun, dikelompokkan, diinterprestasikan, dan dianalisis untuk mengetahui penerapan sistem akuntansi pengeluaran kas atas uang persediaan (UP) pada Dinas Pertanian dan Peternakan Provinsi Sulawesi Utara.Data-data yang diperlukan dalam penelitian ini yaitu Data kualitatif, yaitu data yang disajikan secara deskriptif atau dalam bentuk uraian atau penjelasan serta tidak dapat diukur dalam angka-angka dan Data kuantitatif, yaitu data yang diukur dalam skala numeric (angka). Sumber data dalam penelitian ini adalah data Primer dan data Sekunder.Teknik pengumpulan data yaitu Penelitian kepustakaan, penelitian lapangan dan observasi.Arsyad (2010) mengemukakan Data adalah keterangan mengenai sesuatu yang berguna untuk menganalisa suatu permasalahan dan selanjutnya mencari alternatif pemecahan. Jenis penelitian ini menggunakan penelitian kualitatif yaitu data yang disajikan secara deskriptif atau dalam bentuk uraian atau penjelasan serta tidak dapat diukur dalam angka-angka.

\section{HASIL PENELITIAN DAN PEMBAHASAN}

\section{Gambaran Umum Perusahaan}

"DINAS PERTANIAN DAN PETERNAKAN PROVINSI SULAWESI UTARA" dibentuk berdasarkan Peraturan Gubernur Nomor 57 Tahun 2008 Tentang Uraian Tugas Dinas Pertanian dan Peternakan Provinsi Sulut, Peraturan Gubernur Nomor 91 Tahun 2008 Tentang Pembentukan Unit Pelaksana Tugas Dinas (UPTD) Dinas Pertanian dan Peternakan Provinsi Sulut.

\section{Struktur Organisasi}

Secara umum, susunan organisasi Dinas Pertanian dan Peternakan Provinsi Sulawesi Utara berdasarkan Peraturan Gubernur Nomor 57 Tahun 2008 Tentang Uraian Tugas Dinas Pertanian dan Peternakan Provinsi Sulut, Peraturan Gubernur Nomor 91 Tahun 2008 Tentang Pembentukan Unit Pelaksana Tugas Dinas (UPTD) Dinas Pertanian dan Peternakan Provinsi Sulut adalah sebagai berikut :

1. Kepala Dinas

2. Sekretaris

3. Bidang-Bidang

4. Unit Pelaksana Teknis Dinas (UPTD)

5. Kelompok Jabatan Fungsional

Sekretariat, terdiri dari :

1. Sub Bagian Hukum dan Kepegawaian

2. Sub Bagian Perencanaan dan Keuangan

3. Sub Bagian Umum

Bagian Sekretariat dan masing-masing Sub Bagian dipimpin oleh seorang Kepala.

Bidang-Bidang, terdiri dari :

a. Bidang Pengelolaan Lahan dan Air membawakan :

1. Seksi Pengelolaan Air

2. Seksi Pengelolaan Lahan 


\section{Seksi Perluasan Areal}

b. Bidang Tanaman Pangan dan Hortikultura membawakan :

1. Seksi Tanaman Pangan

2. Seksi Hortikultura

3. Seksi Sarana Produksi

c. Bidang Peternakan membawakan :

1. Seksi Ternak Ruminansia

2. Seksi Ternak Non Ruminansia

3. Seksi Pengamanan Ternak dan Bahan Asal Ternak

d. Bidang Pengolahan dan Pemasaran Hasil membawakan :

1. Seksi Penanganan Pasca Panen

2. Seksi Pengolahan Hasil Pertanian

3. Seksi Pemasaran Hasil Pertanian

e. Unit Pelaksana Teknis Daerah (UPTD), terdiri dari :

1. Balai Perlindungan Tanaman Pangan dan Hortikultura (BPTPH)

2. Balai Pengawasan dan Sertifikasi Benih Tanaman Pangan dan Hortikultura (BPSBTPH)

3. Balai Benih Tanaman Pangan dan Hortikultura (BPTPH)

4. Balai Pengembangan Bibit dan Pakan Ternak (BPBPT)

5. Balai Kesehatan Hewan dan Kesehatan Masyarakat Veteriner (Keswan Kesmavet)

6. Balai Pelatihan Teknis Pertanian

7. Sekolah Pertanian Pembangunan Negeri

f. Kelompok Jabatan Fungsional

1. Kelompok Jabatan Fungsional mempunyai tugas melaksanakan sebagian tugas dinas sesuai dengan keahlian dan kebutuhan;

2. Kelompok Jabatan Fungsional terdiri dari sejumlah tenaga fungsional yang diatur dan ditetapkan berdasarkan peraturan perundang-undangan;

3. Kelompok jabatan fungsional dipimpin oleh seorang tenaga fungsional senior yang ditunjuk;

4. Jumlah tenaga fungsional ditentukan berdasarkan kebutuhan dan beban kerja;

Jenis dan jenjang jabatan fungsional diatas diatur berdasarkan peraturan perundang-undangan.

Tugas Pokok dan Fungsi

Tugas Pokok Dinas Pertanian dan Peternakan Provinsi adalah melaksanakan urusan pemerintahan daerah berdasarkan asas otonomi dan tugas pembantuan dibidang pertanian dan peternakan.

Untuk melaksanakan tugas pokok diatas, Dinas Pertanian dan Peternakan mempunyai fungsi :

a) Perumusan kebijakan teknis dibidang Pertanian dan Peternakan;

b) Penyusunan perencanaan, pengkoordinasian,pembinaan dan pengendalian pelaksanaan tugas;

c) Penyelenggaraan urusan pemerintahan dan pelayanan umum di bidang pertanian dan peternakan;

d) Pelaksanaan tugas lain yang diberikan oleh Gubernur dibidang pertanian dan peternakan.

Visi dan Misi

a. Visi

Terwujudnya pertanian unggul berkelanjutan yang berbasis sumber daya lokal untuk meningkatkan produksi pangan, nilai tambah, daya saing serta kesejahteraan petani.

b. Misi

1. Menciptakan system pertanian yang efisien, berbasis iptek dan sumber daya lokal yang berwawasan lingkungan.

2. Meningkatkan kualitas produk segar melalui pengembangan pertanian organik serta pengembangan diversifikasi produk olahan.

3. Mengamankan plasma-nuftah dan meningkatkan pendayagunaannya untuk mendukung diversifikasi dan ketahanan pangan

4. Menjadikan petani yang kreatif, inovatif dan mandiri serta mampu memanfaatkan iptek dan sumberdaya lokal untuk menghasilkan produk pertanian berdaya saing tinggi.

5. Meningkatkan produksi dan mutu produk pertanian sebagai bahan baku industri.

6. Meningkatkan pendapatan dan kesejahteraan petani 


\section{Hasil Penelitian}

Dinas Pertanian dan Peternakan Provinsi Sulawesi Utara sebagai Dinas Daerah, dipimpin oleh seorang Kepala Dinas yang berada di bawah dan bertanggung jawab kepada Gubernur melalui Sekretaris Daerah Provinsi. Sistem Akuntansi Pengeluaran Kas yang ada di Satuan Kerja Perangkat Daerah (SKPD) Dinas Pertanian dan Peternakan Provinsi Sulawesi Utara terdiri atas 4 sub sistem yaitu :

a. Sub Sistem Akuntansi Pengeluaran Kas-Pembebanan Uang Persediaan (UP)

b. Sub Sistem Akuntansi Pengeluaran Kas-Pembebanan Ganti Uang Persediaan (GU)

c. Sub Sistem Akuntansi Pengeluaran Kas-Pembebanan Tambahan Uang Persediaan (UP)

d. Sub Sistem Akuntansi Pengeluaran Kas-Pembebanan Langsung (LS)

Dalam penelitian ini dibatasi pada Sub Sistem Akuntansi Penegeluaran Kas-Pembebanan Ganti Uang

(GU) Persediaan. Prosedur Sub Sistem Akuntansi Pengeluaran Kas Atas Uang Persediaan (UP) dalam bentuk Pembebanan Ganti Uang (GU), terdiri atas :

1. Penerbitan Surat Penyediaan Dana (SPD)

SPD adalah Surat Penyediaan Dana, yang dibuat oleh BUD (Bendahara Umum Daerah) dalam rangka manajemen kas daerah. SPD digunakan untuk menyediakan dana bagi tiap-tiap SKPD dalam waktu tertentu. Informasi dalam SPD menunjukkan secara jelas alokasi tiap kegiatan.

SPD yang diterbitkan terdiri atas 3 (tiga) lembar, terdiri atas : (1) Lembar 1 diterima oleh Bendahara Pengeluaran Pembantu-SKPD; (2) Lembar 2 diterima oleh Bendahara Pengeluaran-SKPD; (3) Lembar 3 sebagai arsip PPKD selaku BUD.

Pihak Terkait :

a. Kuasa BUD

Dalam kegiatan ini, kuasa BUD mempunyai tugas :

1) Menganalisa DPA-SKPD yang ada di database

2) Menganalisa anggaran kas pemerintah khususnya data per SKPD

3) Menyiapkan draft SPD

4) Mendistribusikan SPD kepada para pengguna anggaran

b. PPKD

Dalam kegiatan ini, PPKD mempunyai tugas :

1) Meneliti draft SPD yang diajukan kuasa BUD

2) Melakukan otorisasi SPD

Prosedur pengajuan SPD-GU secara rinci adalah :

a. Setelah penetapan anggaran kas, PPKD dalam rangka manajemen kas menerbitkan SPD, berdasarkan surat permintaan dari SKPD

b. SPD disiapkan oleh kuasa BUD untuk ditandatangani oleh PPKD

c. Pengeluaran kas atas beban APBD dilakukan berdasarkan SPD atau dokumen lain yang dipersamakan dengan SPD

2. Pengajuan Surat Permintaan Pembayaran (SPP)

Berdasarkan SPD atau dokumen lain atau yang dipersamakan dengan SPD, bendahara pengeluaran mengajukan SPP (Surat Perintah Pembayaran) kepada Pengguna Anggaran/Kuasa Pengguna Anggaran melalui Pejabat Penatausahaan Keuangan SKPD (PPK-SKPD). SPP Uang Persediaan (SPP-UP) dipergunakan untuk mengisi uang persediaan (UP) tiap-tiap SKPD. Pengajuan SPP-UP hanya dilakukan sekali dalam setahun, selanjutnya untuk mengisi saldo uang persediaan akan menggunakan SPP-GU.

SPP Ganti Uang (SPP-GU) dipergunakan untuk mengganti UP yang sudah terpakai.Diajukan ketika UP habis.

SPP UP yang diajukan dibuat rangkap 3 (tiga) : (1) Lembar 1 dan 2 untuk Bendahara Pengeluaran yang akan diteruskan ke PPK-SKPD dan PPKD, setelah ditandatangani oleh Bendahara Pengeluaran. (2) Lembar 3 diarsip oleh Bendahara Pengeluaran Pembantu. Sedangkan SPP-GU yang diajukan dibuat rangkap 2 yang duaduanya diserahkan ke Bendahara Pengeluaran.

Pihak Terkait :

a. Bendahara Pengeluaran

Dalam kegiatan ini, Bendahara Pengeluaran mempunyai tugas :

1) Mempersiapkan dokumen SPP beserta lampiran-lampirannya 


\section{2) Mengajukan SPP kepada PPK-SKPD}

b. PPK-SKPD (Pejabat Pengelola Keuangan-SKPD)

Dalam kegiatan ini, PPK-SKPD mempunyai tugas :

1) Menguji kelengkapan dan kebenaran SPP yang diajukan Bendahara Pengeluaran

Prosedur pertanggungjawaban dan pengajuan SPP-GU secara rinci adalah :

a. Bersamaan dengan membuat SPJ-UP, Bendahara Pengeluaran juga membuat Surat Permintaan Pembayaran Ganti Uang (SPP-UP)

b. Bendahara Pengeluaran kemudian menandatangani SPP-GU dan menyerahkannya ke PPK-SKPD.

c. Kelengkapan dokumen SPP-GU terdiri atas :

1) Surat Pengantar SPP-GU

2) Ringkasan SPP-GU

3) Rincian penggunaan SP2D-UP/GU yang lalu

4) Bukti transaksi yang sah dan lengkap

5) Salinan SPD

6) Draf surat pernyataan Pengguna Anggaran/Kuasa Pengguna Anggaran yang menyatakan bahwa uang yang diminta tidak dipergunakan untuk keperluan lain selain ganti uang persediaan (UP)

7) Lampiran lain yang diperlukan

\section{Penerbitan Surat Permintaan Membayar (SPM)}

Proses penerbitan SPM adalah tahapan penting dalam penatausahaan pengeluaran yang merupakan tahap lanjutan dari proses pengajuan SPP. Sebagai tahap lanjutan, SPM juga dibedakan menjadi 4 (empat) sesuai dengan jenis SPPnya, yaitu SPM-UP, SPM-GU, SPM-TU dan SPM-LS.

SPM dapat diterbitkan jika :

a. Pengeluaran yang diminta tidak melebihi pagu anggaran yang tersedia

b. Didukung dengan kelengkapan dokumen sesuai dengan peraturan perundang-undangan

Waktu pelaksanaan penerbitan SPM :

a. Diterbitkan paling lambat 2 (dua) hari sejak SPP diterima

b. Apabila ditolak, dikembalikan paling lambat 1 (satu) hari sejak diterima SPP

SPM yang diajukan dibuat rangkap 3 (tiga), antara lain :

a. Lembar 1 dan 2 untuk Kepala SKPD/Pengguna Anggaran yang diteruskan ke PPKD dan PPK SKPD, setelah ditandatangani oleh Kepala SKPD/Pengguna Anggaran

b. Lembar 3 diarsip oleh Bendahara Pengeluaran Pembantu

Pihak Terkait :

a. PPK-SKPD

Dalam kegiatan ini, PPK-SKPD memiliki tugas sebagai berikut :

1) Menguji SPP beserta kelengkapannya

2) Membuat rancangan SPM atas SPP yang telah diuji kelengkapan dan kebenarannya dan mengajukan ke Pengguna Anggaran

3) Menerbitkan Surat Penolakan SPM bila SPP yang diajukan oleh Bendahara SKPD tidak lengkap

4) Membuat register SPM

b. Pengguna Anggaran

Dalam kegiatan ini, Pengguna Anggaran memiliki tugas sebagai berikut :

1) Mengotorisasi dan menerbitkan SPM

2) Mengotorisasi Surat Penolakan SPM yang diterbitkan PPK-SKPD bila SPP yang diajukan bendahara SKPD tidak lengkap.

\section{Pembahasan}

Evaluasi atas sistem akuntansi dimaksudkan agar penulis dapat memahami setiap dokumen, catatan akuntansi, pihak yang terkait dan prosedur yang digunakan dalam proses Pengeluaran Kas Atas Uang Persediaan (UP) dalam bentuk Ganti Uang (GU), pada Dinas Pertanian dan Peternakan Provinsi Sulawesi Utara.

Mekanisme penggunaan Uang Persediaan (UP) hanya dapat digunakan untuk pengeluaran rutin SKPD dan pengeluaran - pengeluaran pada program dan kegiatan pada pos Belanja Barang dan Jasa yang bersifat kecil dengan nominal < 10 Juta. UP (Uang Persediaan) diisi kembali dengan mekanisme Ganti Uang (GU). 
Adapun pengeluaran-pengeluaran rutin SKPD Dinas Pertanian dan Peternakan Provinsi Sulawesi Utara yang tertata dalam DPA (Dokumen Pelaksanaan Anggaran) tahun 2014 terdiri atas :

A. Program Pelayanan Adminsitrasi Perkantoran

1. Kegiatan penyediaan kebutuhan administrasi umum

2. Kegiatan penyediaan kebutuhan admistrasi keuangan

3. Kegiatan penyediaan kebutuhan administrasi barang/jasa

4. Kegiatan penyediaan kebutuhan administrasi kepegawaian

5. Kegiatan pelaksanaan rapat koordinasi dan konsultasi

Penelitian ini didukung oleh penelitian terdahulu Christien Natalia Supit, 2014, Evaluasi Sistem Akuntansi Pengeluaran Kas Atas Pencairan Kredit, kasus pada PT. BANK BUKOPIN, Tbk.Tujuan penelitian ini adalah untuk mengevaluasi sistem informasi akuntansi pengeluaran kas atas pencairan kredit yang meliputi evaluasi fungsi yang terkait, dokumen yang digunakan, catatan akuntansi yang digunakan, prosedur pencairan kredit dan bagan alir yang digunakan pada Bank Bukopin. Metode analisis yang digunakan yaitu metode analisis deskriptif, yaitu suatu metodepenelitian yangmelakukan penjelasan, evaluasi dan mengklasifikasikan data dan informasi yang diperoleh dengan berbagai teknik yaitu wawancara, observasi dan lain-lain sehingga sampai pada satu kesimpulan yang relevan dengan teori. Berdasarkan hasil penelitian sistem informasi akuntansi pengeluaran kas atas pencairan kredit pada Bank Bukopin telah dilaksanakan sesuai dengan fungsi masingmasing bagian yang telah ditetapkan yaitu adanya pemisahan tugas dimasing-masing unit kerja dan telah sesuai dengan Prosedur dan Pedoman Kerja Operasi (PKO) Bank. Sistem akuntansi pengeluaran kas atas pencairan kredit pada PT Bank Bukopin Tbk sudah memiliki flowchart yang baku, namun seringkali tidak dijalankan dengan baik. Pencairan kredit dilakukan sesuai dengan prosedur dan pedoman kerja yang telah ditetapkan. PT Bank Bukopin, Tbk harus selalu menjalankan fungsi pada unit kerjanya sesuai dengan prosedur dan harus selalu mengikuti bagan alir flowchart yang ada agar tidak terjadi kesalahpahaman antar karyawan sehingga proses yang ada menjadi lebih cepat.

\section{Kesimpulan}

\section{PENUTUP}

Berdasarkan hasil penelitian dan pembahasan pada bab-bab sebelumnya, maka penulis menarik kesimpulan sebagai berikut:

1. Pelaksanaan sistem akuntansi pengeluaran kas atas uang persediaan di Dinas Pertanian dan Peternakan Provinsi Sulawesi Utara telah dilakukan sesuai dengan teori sistem akuntansi pengeluaran kas serta aturan yang ada mencakup fungsi yang terkait, dokumen yang digunakan, catatan akuntansi yang digunakan dan jaringan prosedur sistem akuntansi pengeluaran kas.

2. Sistem akuntansi pengeluaran kas atas uang persediaan pada Dinas Pertanian dan Peternakan Provinsi Sulawesi Utara, sudah memiliki flowchart yang baku, namun seringkali tidak dijalankan dengan baik.

\section{Saran}

1. Dalam pelaksanaan sistem penatausahaan pengelolaan keuangan daerah dibutuhkan tenaga sumber daya manusia atau pegawai untuk menjalankan perangkat pendukung yang digunakan dalam sistem akuntansi pengeluaran kas tersebut. Sehubungan dengan aplikasi Sistem Akuntansi Pemerintah Daerah yang merupakan program tersendiri, maka dibutuhkan lebih banyak pegawai yang mengerti dengan baik dan dapat menjalankan secara benar program aplikasi tersebut.

2. Dalam pelaksanaan sistem akuntansi pengeluaran kas membutuhkan perangkat pendukung teknis yang mampu bekerja dan digunakan optimal sehingga penyusunan laporan dapat dilakukan dengan baik. Perangkat pendukung teknis merupakan unit komputer yang mampu melaksanakan perhitungan-perhitungan dengan cepat dan akurat.

3. Diharapkan adanya pelatihan dalam bidang akuntansi agar dalam proses kinerja dapat berjalan sesuai yang diharapkan.

\section{DAFTAR PUSTAKA}

Harahap, Sofyan Syafri. 2011. Teori Akuntansi. Penerbit PT. Raja Grafindo Persada : Jakarta

Mulyadi, 2010.Sistem Akuntansi edisi 3: Salemba Empat : Jakarta 
Umbuan V, 2012. Perancangan Sistem Informasi Akuntansi.Yogjakarta

Christien Natalia Supit, 2014. Evaluasi Sistem Akuntansi Pengeluaran Kas Atas Pencairan Kredit.

Pemerintah Republik Indonesia (2008) Peraturan Gubernur Nomor 57 tentang Uraian Tugas Dinas Pertanian dan Peternakan Provinsi Sulawesi Utara

Pemerintah Republik Indonesia (2007) Pedoman Pengelolaan Keuangan Daerah Permendagri Nomor 57

Mulyadi. 2008. Akuntansi Keuangan Daerah. Edisi Kedua. PT. Indeks. Jakarta.

Tanjung, Abdul Hafiz., 2012 Akuntansi Pemerintah Daerah Berbasis Akrual. Alfabeta. Bandung.

Soemarso, 2009. Akuntansi Keuangan Daerah, Edisi 3, Penerbit Salemba Empat, Jakarta.

Arsyad, 2010

Pemerintah Republik Indonesia 2007.Peraturan Pemerintah Republik Indonesia No. 57 tentang Pengelolaan Keuangan Daerah. Jakarta.

Pemerintah Republik Indonesia 2010.Peraturan Pemerintah Republik Indonesia No. 17 tentang Standar Akuntansi Pemerintahan. Jakarta. 